\title{
Goblet Cell Adenocarcinoma With Heterotopic Ossification: A Rare Case Report and Review of Literature
}

\author{
Mohammed Alghamdi ${ }^{1}$, Tiffani Mathew ${ }^{2}$, Andrea Breaux ${ }^{2}$, Harpreet Chopra ${ }^{2}$ \\ 1. Pathology, University of Louisville School of Medicine, Louisville, USA 2. Pathology and Laboratory Medicine, \\ University of Louisville, Louisville, USA
}

Corresponding author: Mohammed Alghamdi, alghamdm@mskcc.org

\begin{abstract}
Heterotopic bone formation is a rare phenomenon when associated with gastrointestinal neoplasms. Here we present a rare case of heterotopic ossification associated with goblet cell adenocarcinoma of the appendix, and a literature review of such cases associated with neoplasms within and out of the gastrointestinal tracts. We reviewed the clinical data and when available, immunohistochemical markers of osteoblastic differentiation. Our review shows similar findings to prior reports of apparent high association of heterotopic bone formation with neoplasms with mucinous features. Two, previously proposed main hypotheses of the mechanisms are reviewed. The unique feature about this case is that goblet cell adenocarcinoma was not reported previously in the setting of bone formation.
\end{abstract}

Received 05/04/2020 Review began 05/14/2020 Review ended 05/18/2020 Published 05/27/2020

() Copyright 2020 Alghamdi et al. This is an open access article distributed under the terms of the Creative Commons Attribution License CC-BY 4.0., which permits unrestricted use, distribution, and reproduction in any medium, provided the original author and source are credited.
Categories: Pathology, Radiology, Gastroenterology

Keywords: heterotopic bone, ossification, goblet cell adenocarcinoma

\section{Introduction}

Heterotopic ossification is defined as the formation of lamellar ectopic bone in the soft tissue [1]. It is commonly seen in various anatomic locations including muscles and joints. It can be associated with clinical scenarios such as burns, prolonged bedridden states secondary to brain injuries, and certain orthopedic surgeries [1]. Males tend to have a higher incidence possibly due to differences in muscle mass, mechanism of injury, and hormonal status that affects osteogenesis [1-2]. Here, we report a case of heterotopic ossification associated with goblet cell adenocarcinoma of appendiceal origin. Studying the upregulation of chondrogenic and osteogenic genes in the injured soft tissue as well as the tumor cells/microenvironment has been previously performed by other investigators and may help us understand the pathogenesis of this phenomenon.

\section{Case Presentation}

\section{Clinical history}

A 57-year-old female patient, presented with severe, intermittent abdominal pain, worsening in intensity. Abdominopelvic CT scan was performed and revealed a large pelvic mass in addition to small intestinal thickening (Figure 1). The patient was taken to the OR for total abdominal hysterectomy, bilateral salpingooophorectomy with tumor debulking. On intraoperative frozen section consultation, the ovary was involved by a malignant neoplasm. Histologic examination on paraffin-embedded sections showed an adenocarcinoma with signet ring cell features involving pelvic organs and omentum. Immunohistochemical studies were performed and showed immunoreactivity for CK20 and CDX2, consistent with a gastrointestinal primary. The gastrointestinal origin of this tumor was not suspected at the time of the surgery, hence the appendix was not resected. The oncology service started the patient on FOLFOX regimen (Folinic acid, Fluorouracil, Oxaliplatin). The patient completed a total of 12 cycles of FOLFOX with hyperthermic intraperitoneal chemotherapy (HIPEC) and underwent a right hemicolectomy after the eighth cycle of FOLFOX. 


\section{Cureus}
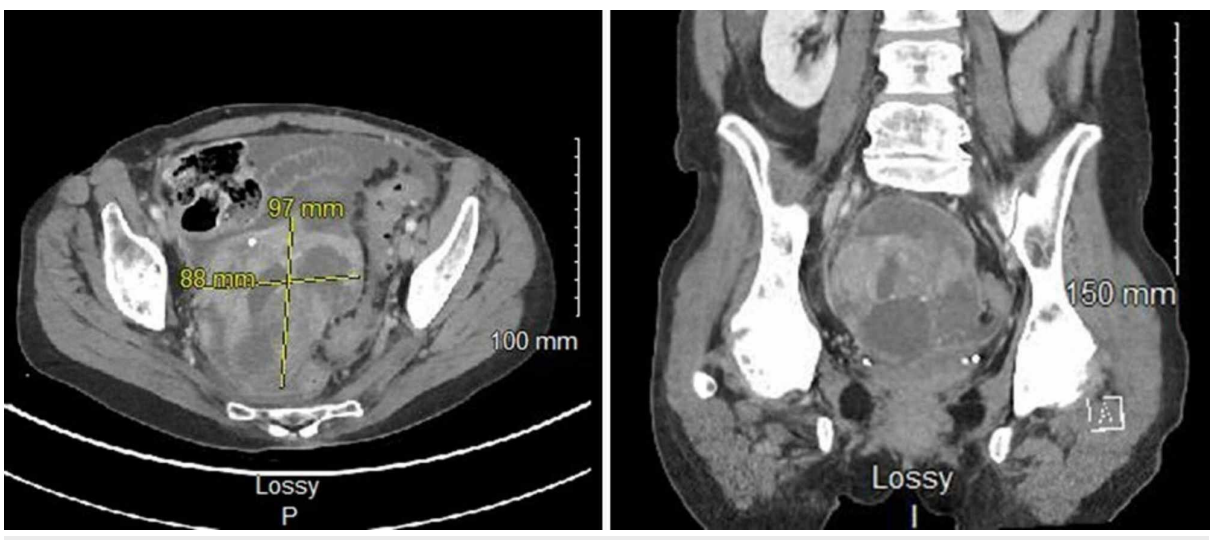

FIGURE 1: CT scan for abdomen and pelvis with contrast shows a large pelvic mass measuring $9.7 \mathrm{~cm} \times 8.8 \mathrm{~cm}$ on the cross-sectional image (left), the coronal section showing lesional punctate hyperdensities compatible with ossification (right).

\section{Surgical intervention and gross examination}

The patient underwent an exploratory laparotomy, right hemicolectomy with en bloc omentectomy, cholecystectomy, and intraperitoneal tumor resection for her surgical management. The main specimen was received as a $30.5 \mathrm{~cm}$ segment of large bowel and terminal ileum with an attached appendix and a moderate amount of attached fibrofatty tissue. The appendix was adherent to the surrounding fibrofatty tissue and measured $5.0 \mathrm{~cm}$ in length $\times 1.2 \mathrm{~cm}$ in diameter. No tumor was grossly identified on the large bowel or ileal mucosa, or at the appendiceal orifice. Sectioning through the appendix revealed an obliterated lumen and a nodule that appeared to be contiguous with the appendiceal surface and wall. The nodule was markedly calcified and measured $2.5 \mathrm{~cm}$ in length $\mathrm{x} 0.9 \mathrm{~cm}$ in diameter and appeared to extend into the periappendiceal fat (Figure 2).

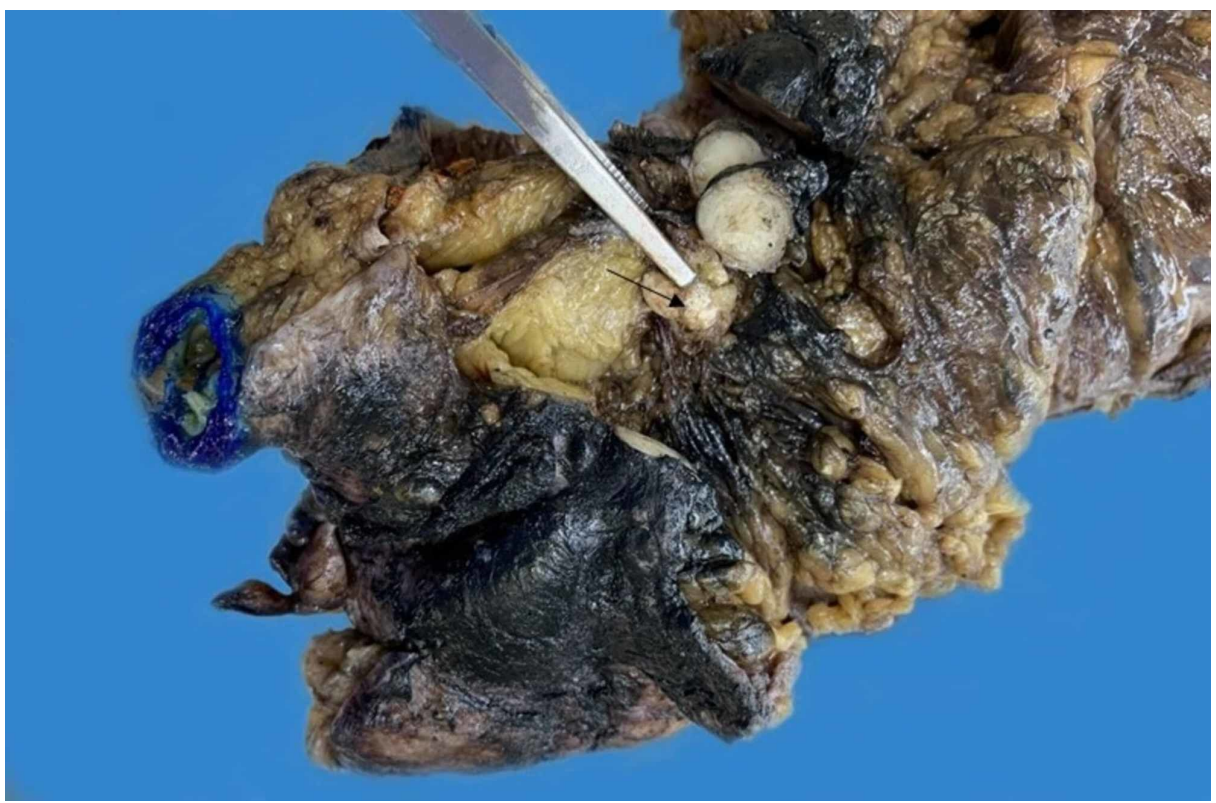

FIGURE 2: Gross photograph of the appendiceal tumor showing the obliterated lumen with calcification at the center (arrow).

\section{Histologic examination}

Hematoxylin and eosin (H\&E) stained slides showed a concentric transmural proliferation of tubules containing cells with minimal nuclear pleomorphism and a moderate amount of eosinophilic cytoplasm, 


\section{Cureus}

along with goblet cells. The tumor cells were surrounded by a desmoplastic reaction and thickening of the appendiceal wall. The appendiceal lumen was obliterated with mature bone formation lined by osteoblasts. The tumor cells extended into the mesoappendix, as well as the adjacent small and large bowel, and there was an extensive perineural invasion. The goblet cells are positive for synaptophysin, chromogranin and CD56, and negative for CK7 (Figure 3).
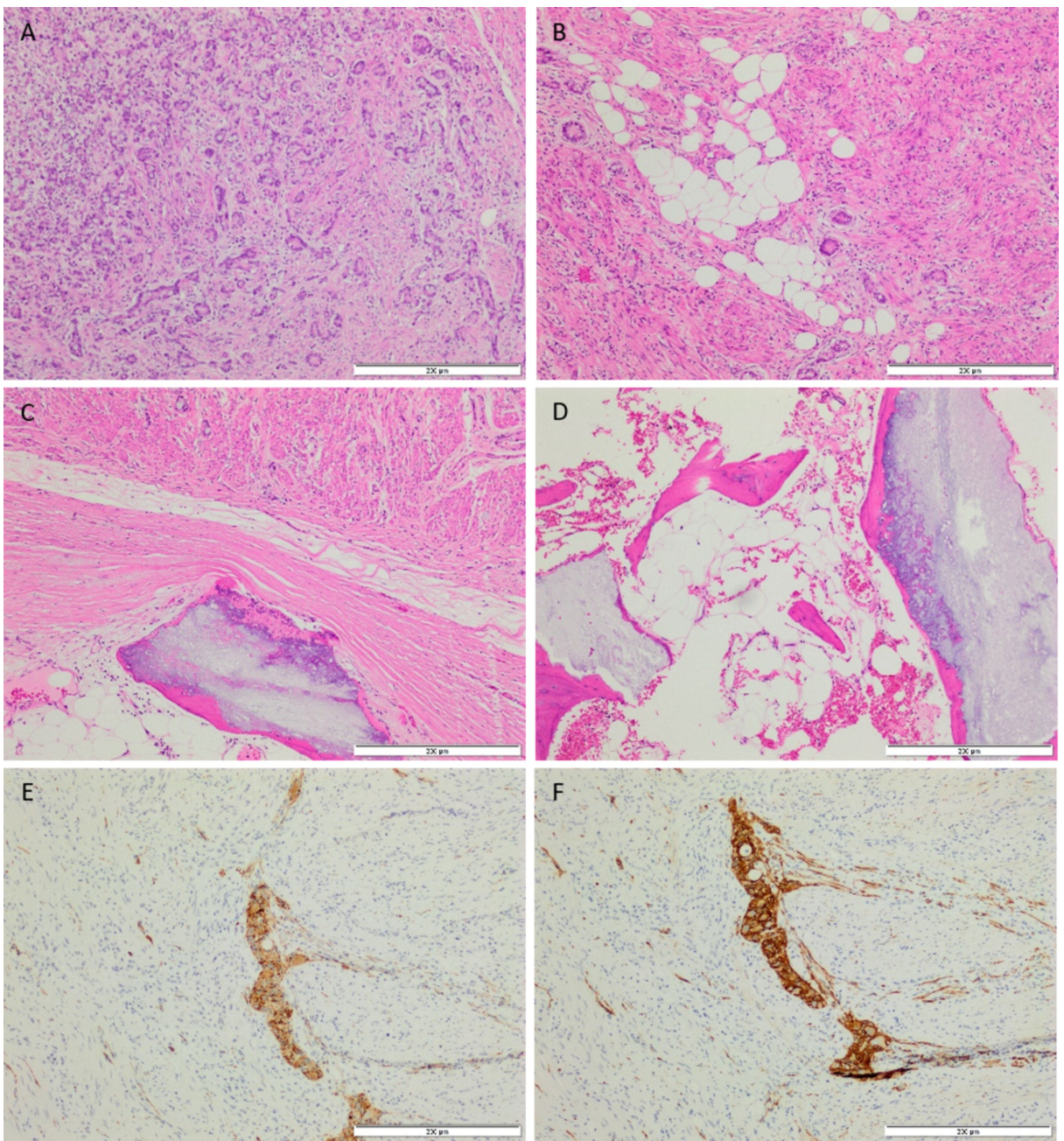

FIGURE 3: Photomicrographs of the appendiceal tumor. (A)

Predominantly tubular proliferation of tumor cells with surrounding desmoplastic reaction. (B) Glandular elements and single cells invading the mesoappendix. (C, D) Formation of bone lined by osteoblasts. (E, F) Show tumor cells positive for synaptophysin and CD56, respectively. (Hematoxylin and Eosin stains and immunohistochemical studies, 20x)

\section{Discussion}

Heterotopic bone formation is reported in association with tumors; some of which are summarized in Table 1. We present here the first reported case of heterotopic ossification in association with goblet cell adenocarcinoma of the appendix. The six case reports, in addition to our case of appendiceal tumors with mucin production and heterotopic ossification are summarized in Table 2. Various hypotheses have been put forth to explain heterotopic ossification in tumors. Huang et al. showed that the formation of bone in neoplastic settings results from pluripotent stromal cells undergoing osseous differentiation as highlighted by differential expression of morphogenic markers between the stroma and tumor cells [3]. Conversely, Noh et al. demonstrated the upregulation of chondrogenic and osteogenic markers in tumor cells favoring the idea of osteoblastic metaplasia of tumor cells [4]. 


\section{Cureus}

\begin{tabular}{|llll|}
\hline Organ & Author & Tumor type & IHC markers tested \\
\hline Colon & Huang et al. (2014) [3] & Adenocarcinoma & Osteonectin, Gli2, Nestin, a-SMA \\
Lung & Suzuki et al. (2019) [5] & Adenocarcinoma & BMP-2, Osteopontin \\
Rectum & Kypson et al. (2003) [6] & Adenocarcinoma & Osteocalcin, Osteopontin, $\beta$-catenin, BMP9 \\
Thyroid & Takeda et al. (2013) [7] & Papillary thyroid carcinoma & bFGF, BMP-2, VEGF \\
Lung & Kim et al. (2009) [8] & Adenocarcinoma & TGF- $\beta$ 1, Osteopontin, Osteocalcin, Runx2 \\
Lung & Tsubochi et al. (2013) [9] & Carcinoid tumor & BMP-2, Osteocalcin \\
Rectum & Smajda et al. (2015) [10] & Adenocarcinoma & Not performed \\
\hline
\end{tabular}

TABLE 1: Summary of reported cases of neoplasia with heterotopic ossification and immunohistochemical studies performed.

Gli2: glioma-associated oncogene family zinc finger 2, a-SMA: smooth muscle actin, BMP-2: bone morphogenetic protein 2, BMP-9: bone morphogenetic protein 9, bFGF: basic fibroblast growth factor, VEGF: vascular endothelial growth factor, TGF- $\beta 1$ : transforming growth factor, Runx2: Runt-related transcription factor 2.

\begin{tabular}{|c|c|c|c|c|c|}
\hline Case & $\begin{array}{l}\text { Age } \\
\text { (sex) }\end{array}$ & Past medical history & Diagnosis & $\begin{array}{l}\text { Size } \\
\text { (cm) }\end{array}$ & IHC \\
\hline $\begin{array}{l}\text { Juvara et al. } \\
\text { (1948) [11] }\end{array}$ & $\begin{array}{l}70 \\
(\mathrm{M})\end{array}$ & $\begin{array}{l}\text { Strangulation of a right } \\
\text { inguinoscrotal hernia }\end{array}$ & Perforated mucocele & 7.0 & NA \\
\hline $\begin{array}{l}\text { Haque et al. } \\
\text { (1996) [12] }\end{array}$ & $46(F)$ & $\begin{array}{l}\text { Chronic ulcerative colitis, in } \\
\text { remission }\end{array}$ & Mucinous cystadenocarcinoma & 2.0 & NA \\
\hline $\begin{array}{l}\text { Choi et al. } \\
(2016)[13]\end{array}$ & 44(F) & Papillary thyroid carcinoma & Mucinous cystadenoma & 3.5 & NA \\
\hline $\begin{array}{l}\text { Choi et al. } \\
(2016)[13]\end{array}$ & $56(\mathrm{~F})$ & Abdominal pain & $\begin{array}{l}\text { Low-grade appendiceal mucinous } \\
\text { neoplasm }\end{array}$ & 7.0 & NA \\
\hline $\begin{array}{l}\text { Choi et al. } \\
(2016)[13]\end{array}$ & $58(\mathrm{~F})$ & Incidental pelvic mass & Mucinous cystadenocarcinoma & 8.0 & NA \\
\hline $\begin{array}{l}\text { Noh et al. } \\
(2016)[4]\end{array}$ & $72(\mathrm{~F})$ & $\begin{array}{l}\text { Dyspepsia, weight loss, } \\
\text { hyperlipidemia }\end{array}$ & $\begin{array}{l}\text { Perforated low-grade appendiceal } \\
\text { mucinous neoplasm }\end{array}$ & 8.0 & $\begin{array}{l}\text { BMP9, ALK1, Osteocalcin, } \\
\text { Osteopontin }\end{array}$ \\
\hline Current case & $\begin{array}{l}57 \\
(\mathrm{M})\end{array}$ & Abdominal pain & $\begin{array}{l}\text { Adenocarcinoma ex goblet cell } \\
\text { carcinoid }\end{array}$ & 5.0 & NA \\
\hline
\end{tabular}

TABLE 2: Reported cases of neoplasia from the appendix with heterotopic ossification.

BMP9: bone morphogenetic protein 9, ALK1: anaplastic lymphoma kinase 1

\section{Conclusions}

As more cases are reported, a probable mechanism for heterotopic ossification associated with neoplasia is gaining better understanding. Further studies to assess the clinical significance of bone formation in these tumors, and possible correlation with tumor behavior are warranted. One of the limitations of this case report is the lack of morphoproteomic analysis via immunohistochemistry due to financial reasons.

\section{Additional Information}

\section{Disclosures}

Human subjects: Consent was obtained by all participants in this study. Conflicts of interest: In 
compliance with the ICMJE uniform disclosure form, all authors declare the following: Payment/services info: All authors have declared that no financial support was received from any organization for the submitted work. Financial relationships: All authors have declared that they have no financial relationships at present or within the previous three years with any organizations that might have an interest in the submitted work. Other relationships: All authors have declared that there are no other relationships or activities that could appear to have influenced the submitted work.

\section{References}

1. Ranganathan K, Loder S, Agarwal S, et al.: Heterotopic ossification: basic-science principles and clinical correlates. J Bone Joint Surg Am. 2015, 97:1101-1111. 10.2106/JBJS.N.01056

2. Dey D, Wheatley BM, Cholok D, et al.: The traumatic bone: trauma-induced heterotopic ossification . Transl Res. 2017, 186:95-111. 10.1016/j.trsl.2017.06.004

3. Huang RS, Brown RE, Buryanek J: Heterotopic ossification in metastatic colorectal carcinoma: case report with morphoproteomic insights into the histogenesis. Ann Clin Lab Sci. 2014, 44:99-103.

4. Noh BJ, Kim YW, Park YK : A rare colon cancer with ossification: pathogenetic analysis of bone formation . Ann Clin Lab Sci. 2016, 46:428-432.

5. Suzuki J, Kanauchi N, Endo M, et al.: Pulmonary adenocarcinoma with heterotopic ossification . Kyobu Geka. 2019, 72:363-366

6. Kypson AP, Morphew E, Jones R, et al.: Heterotopic ossification in rectal cancer: Rare finding with a novel proposed mechanism. J Surg Oncol. 2003, 82:132-136. 10.1002/jso.10181

7. Takeda M, Mikami T, Numata Y, et al.: Papillary thyroid carcinoma with heterotopic ossification is a special subtype with extensive progression. Am J Clin Pathol. 2013, 139:587-598. 10.1309/AJCPQZQN50HKIAHA

8. Kim GY, Kim J, Kim TS, et al.: Pulmonary adenocarcinoma with heterotopic ossification . J Korean Med Sci. 2009, 24:504-510. 10.3346/jkms.2009.24.3.504

9. Tsubochi H, Endo S, Oda Y, et al.: Carcinoid tumor of the lung with massive ossification: report of a case showing the evidence of osteomimicry and review of the literature. Int J Clin Exp Pathol. 2013, 6:957-961.

10. Smajda S, Danse E, Mertens de Wilmars M, et al.: Ossification of a rectal tumor: an uncommon finding . Acta Gastroenterol Belg. 2015, 78:431-435.

11. Juvara I, Borcesco U: Ossification of an appendicular mucocele. Br Med J. 1948, 15:931-933. 10.1136/bmj.1.4558.931

12. Haque S, Eisen RN, West AB: Heterotopic bone formation in the gastrointestinal tract. Arch Pathol Lab Med. 1996, 120:666-670

13. Choi SY, Park S, Kim KH, et al.: Heterotopic ossification in appendiceal mucinous neoplasms: clinicopathological characteristics of 3 cases. Malays J Pathol. 2016, 38:49-54. 